\title{
前立腺肥大症の重症度分類の試み
}

\author{
東京大学泌尿器科学教室（主任：阿曾佳郎教授） \\ 本間 之夫 今荘智恵子高橋悟阿曾 佳郎
}

\section{A CLINICAL CLASSIFICATION OF SEVERITY OF BENIGN PROSTATIC HYPERPLASIA}

\author{
Yukio Homma, Chieko Imajo, Satoru Takahashi and Yoshio Aso \\ Department of Urology, Faculty of Medicine, The University of Tokyo
}

(Director: Prof. Yoshio Aso)

The grading of severity of benign prostatic hyperplasia (BPH) was attempted by scoring clinical manifestations associated with the disease. The total score ( 0 to 100 points) is the sum total of subjective and objective one, each of which is 50 points at its maximum. Subjective score is composed of symptom score ( 0 to 25 points) evaluating 5 each obstructive and irritative symptoms and quality of life (QOL) score (0 to 25 points). Objective score consists of functional and anatomical scores. Functional score ( 0 to 25 points) is calculated by scoring maximum flow rate and residual urine. Anatomical score ( 0 to 25 points) is calculated by the score of prostatic volume. Seventy-seven BPH patients have been evaluated by this scoring system. The mean values of 4 kinds of scores (symptom, QOL, functional and anatomical scores) were about 8-9 points and thus comparable each other. The total score was $35.4 \pm 12.3$ in the average and divided into 6 grades: Grade $0 ;<10$, Grade $1 ; \geqq 10$, Grade $2 ; \geq 20$, Grade $3 ; \geqq 30$, Grade $4 ; \geqq 40$, Grade $5 ; \geqq 50$. The present scoring and grading systems appear to be appropriately formulated to estimate the global severity of BPH patients. Further studies to apply the system to evaluation of therapeutic responses would be mandatory to examine its validity.

Key words: benign prostatic hyperplasia, severity, scoring system

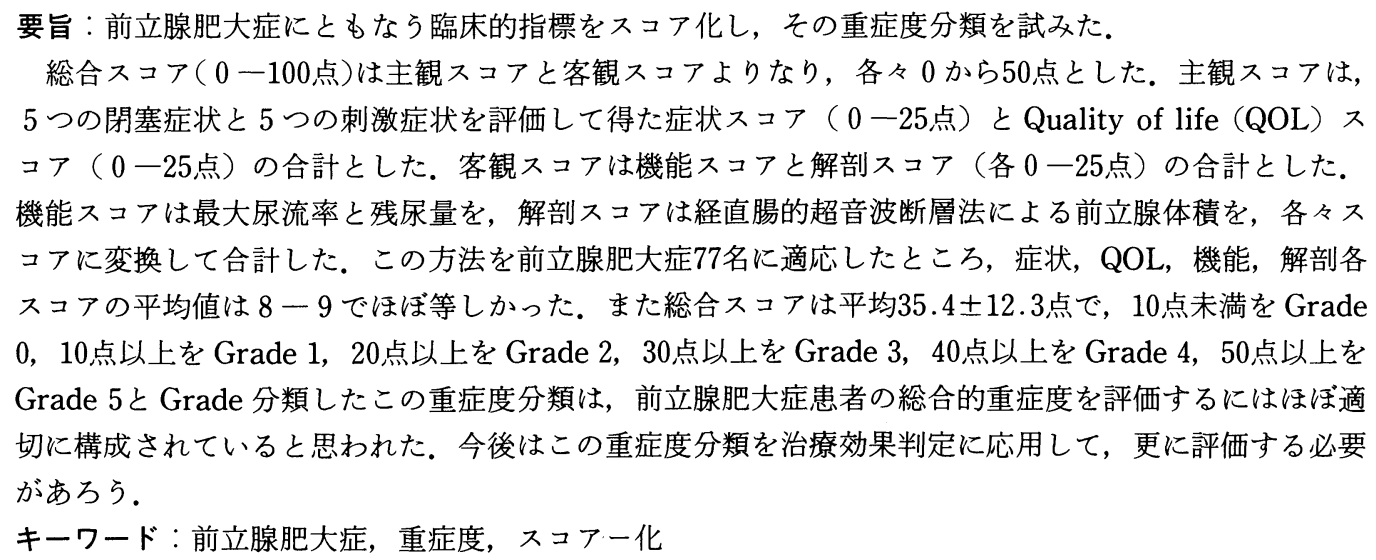

\section{緒 言}

前立腺肥大症は泌尿器科医にとって日常診療で最も 一般的な疾患のひとつである。しかし今後の人口の高 齢化にともない前立腺肥大症患者は増加し, 泌尿器科 医にとどまらず一般の人々の本疾患への関心も高まる ことが予想される。更に最近では，前立腺肥大症に対
して新しい薬物治療 ${ }^{11}$ や物理的治療法として尿道ステ ント ${ }^{2)}$, バルーン拡張 ${ }^{3}$, 温熱療法4), 高温度治療 5 など の低侵襲的治療の試みがなされている.

しかしながら，前立腺肥大症による症状の重症度に ついては, 既にいくつかの試みはあるものの ${ }^{6 / 7)}$, 標準 化された取扱い方法がないのが現状である。このこと 


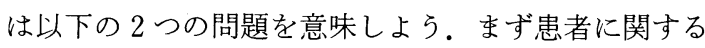
情報が冗長となる，即ち特定の患者の排尿に関する症 状や所見の程度を簡潔に表現できない，第二には，治 療の有効性の判定や比較が困難となる。治療法の研究 ごとに有効性の判定法が異なり, 更にその判定に担当 医の恣意も加わるため, 治療法間の有効性の比較はも ちろん，ある特定の治療法の有効性判定の信憑性も不 確実となる。こうした問題を背景として1991年 6 月に パリで国際会議も開催された。

本研究ではその会議の答申息索考とし前立腺肥大 症の重症度を標準化する試みを行ったので報告する。

\section{方法}

1. 対象

1991年 4 月から1992年 3 月までの 1 年間に, 東京大 学附属病院を受診した前立腺肥大症患者を対象とし た。ただし尿閉，水腎症，血清クレアチニン異常，尿 路感染症のある症例は除外した。診断にあたっては, 一般的な泌尿器科的診察に加えて下記に述べる自覚症 状の問診票調査, 尿流率検査（Dantec 社製 UD5500 MK2), カテーテル择入による残尿測定, 経直腸的前立 腺超音波検査 (Technar 社製 PROSCAN)を行った。 神経因性膀胖，膀胱頸部硬化症の疑いのある症例では, 必要に応じて膀脂内圧測定及び排尿時膀胖尿道造影を 行った。前立腺癌の疑いのある症例では, 生検で癌細 胞の証明されないことを確認した。これらの所見で前 立腺肥大症以外の疾患が排尿障害の原因となっている ことが否定できない症例住除外した。また心不全・糖
尿病その他の全身的な合併症のある症例も検討から除 外した.

2. 重症度の評価方法

前立腺肥大症の重症度をとらえるにあたっては，そ の指標を大きく主観的指標と客観的指標に二分した上 で総合評価を行った。

1）主観的指標（自覚症状）

主観的指標は前立腺国際会議による国際前立腺症状

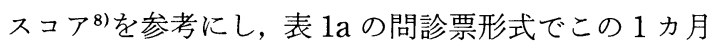
間の平均的状態について聴取した。問診内容は, 排尿 に関するものと排尿障害による生活への影響とに分け て考えた.

排尿状態については，(1)昼間排尿回数，(2)夜間排尿 回数, (3)排尿開始の遅延, (4)排尿時間の延長, (5)排尿 開始時の腹圧, (6)排尿の途絶, (7)尿勢の低下, (8)残尿 感, (9)尿意切迫感, (10) 2 時間以内の排尿の 10 項目につ き，その頻度により表 $1 \mathrm{~b}$ に従って 0 点（ない）から 5 点（ほとんどいつもある）までのスコアをつけた。こ れら症状のうち(1)(2)(8)(9)(10)刺激症状, (3)(4)(5)(6)(7)(8) は閉塞症状である。 また(1)(3)(4)の項目は国際前立腺症 状スコアにないものを加えた。

排尿障害による日常生活への影響については, Quality of Life (QOL) の障害とし, (1)身体的な不快感, (2)精神的な不快感, (3)家庭生活上の支障, (4)社会生活 上の支障について表 1a の回答形式に従って計算し表 $1 \mathrm{~b}$ のように 0 点（なし）から 5 点（非常にあり）のス コアをつけた. 更に, (5)綜合的な満足度として0 点(満

表 1 主観的症状とそのスコア

表1-a 患者への問診形式
[1] 排尿状態についてらかがいます
1. 朝起きた時から夜就寝する時まで，何回排尿しましたか？
2. 夜間の就寝中に, 排尿のために何回起きましたか?
3. トイレに行って尿が出始めるまでに, 時間のかかることがありましたか?
4. 尿が出始めてから終わるまでに, 時間のかかることがありましたか?
5. 排尿をはじめる時, 下腹部に力を入れる必要がありましたか?
6. 排尿の途中で，尿の途切れることがありましたか?
7. 排尿の勢いの弱いことがありましたか?
8. 排尿後, 尿のまだ残っている感じがありましたか?
9. 排尿したくなると, 我慢するのがつらいことがありましたか?
10. 排尿後, 2 時間以内にもら一度行く必要がありましたか?
[2] 排尿状態の日常生活に対する影響についてらかがいます.
1. 排尿状態が原因で，体に感じる不快感がありましたか?
2. 排尿状態が原因で，精神的な不快感がありましたか?
3. 排尿状態が原因で，家庭での生活に支障がありましたか?
4. 排尿状態が原因で，仕事や外出などの社会的な生活に支障がありましたか?
5. 排尿状態が今後ずっと今と同じだとしたら，どう思いすすか？ 
表1-b 回答とそのスコア

\begin{tabular}{|c|c|}
\hline 項 目 & 回 答 と ス \\
\hline$[1]-1$ & $($ 回答 -5$) \div 3=$ スコア $(20$ 回以上 $=5)$ \\
\hline-2 & 回数 $=$ スコア $(5$ 回以上 $=5)$ \\
\hline$-3 \sim 10$ & $\begin{array}{l}\text { なかった }=0 \text {,あまりなかった }(5 \text { 回に } 1 \text { 回より少 } \\
\text { ない)=1, ときどきあった }(3 \sim 5 \text { 回に } 1 \text { 回 })= \\
2,2 \text { 回に } 1 \text { 回ぐらいあった }=3 \text {, しばしばあった } \\
(2 \text { 回に } 1 \text { 回より多い) }=4 \text {, ほとんどいつもあっ } \\
\text { た }=5\end{array}$ \\
\hline$[2]-1 \sim 4$ & $\begin{array}{l}\text { なかった }=0, \text { ほとんどなかった }=1 \text {, すこしあっ } \\
\text { た=2,あった }=3 \text {,かなりあった }=4 \text {, 非常に } \\
\text { あった }=5\end{array}$ \\
\hline-5 & $\begin{array}{l}\text { 満足 }=0, \text { 大体満足 }=1, \text { 満足と不満の中間 }=2, \\
\text { 不満気味 }=3 \text {, 不満 }=4 \text {, 非常に不満 }=5\end{array}$ \\
\hline
\end{tabular}

足）から 5 点（非常に不満）に評価した。国際前立腺 症状スコアでは QOL の評価は(5)の項目に限り，しか も6 点満点としているが，本研究では(1)（4)の項目を 加光，(5)他のスコアとの共通性を保つため 5 点満点 とした。

問診票についてはその再現性が問題となる。そこで 研究初期の 23 症例で，質問項目の順番を適当にか学た 問診票で 2 週間の間隔を括いて繰り返し調査した。そ の結果は表 2 の通りで, 刺激症状 (上 5 項目) 閉塞症 状（下 5 項目）とも再現性はお拈むね良好であった。 QOL に関するスコアは再現性はほぼ同一であった。以 上から再現性は良好と考光, 調査を進めた。

スコアの取扱いは, 表 3 上半部のように, 刺激症状
表 2 自覚症状の 1 回目調査と 2 回目調査のスコアの 相関

\begin{tabular}{l|c|c|c}
\hline & 同 - & 1点差 & 2 点差 \\
\hline 刺激症状 & & & \\
昼間頻尿 & 18 & 4 & 1 \\
夜間頻尿 & 20 & 3 & \\
残尿感 & 21 & 2 & \\
尿意切迫 & 19 & 4 & \\
2 時間排尿 & 18 & 5 & \\
閉塞症状 & & & \\
開始遅延 & 16 & 4 & 3 \\
排尿延長 & 19 & 3 & 1 \\
開始時怒責 & 15 & 6 & 2 \\
尿線途絶 & 16 & 6 & 1 \\
尿勢低下 & 20 & 2 & 1 \\
QOL & & & \\
身体的不快 & 20 & 3 & \\
精神的不快 & 20 & 3 & \\
家庭生活 & 21 & 2 & \\
社会生活 & 19 & 3 & \\
満足度 & 20 & 3 & \\
\hline
\end{tabular}

23例での検討

3 点差以上の組合せはなかった

のスコアと閉塞症状スコア (各々 0 25点) の算術平 均を症状スコア（０２5点）とした，QOL スコア（0 $\sim 25$ 点) は不快・支障スコア $(0 \sim 20$ 点 $)$ と不満スコ ア（０－5点）を加光た。症状スコアとQOL スコアを 加党て主観スコア（０－50点）とした。

2) 客観的指標（他覚所見）

表 3 前立腺肥大症による排尿障害のスコア化

\begin{tabular}{|c|c|c|c|}
\hline スコアの分類 & スコアの範囲 & スコアの計算方法 & \\
\hline 刺激症状スコフ & $(0-25)$ & 問診表 [1] $-1+2+8+9+10$ & $\mathrm{a}$ \\
\hline 閉塞症状スコア & $(0-25)$ & 問診表 $[1]-3+4+5+6+7$ & $\mathrm{~b}$ \\
\hline 症状スコア & $(0-25)$ & $(a+b) / 2$ & $\mathrm{~S}$ \\
\hline 不快・支障スコフ & $(0-20)$ & 問診表 $[2]-1+2+3+4$ & c \\
\hline 不満スコア & $(0-5)$ & 問診表 [2] -5 & d \\
\hline $\mathrm{QOL}$ スコア & $(0-25)$ & $c+d$ & $\mathrm{~L}$ \\
\hline 主観スコア & $(0-50)$ & $\mathrm{S}+\mathrm{L}$ & Sbj \\
\hline 尿流率スコア & $(0-15)$ & 15-最大尿流率 (ml/s) & e \\
\hline 残尿スコア & $(0-10)$ & $\sqrt{\text { 残尿量 }(\mathrm{ml}) / 4}$ & $\mathrm{f}$ \\
\hline 機能スコア & $(0-25)$ & $e+f$ & $\mathrm{~F}$ \\
\hline 前立腺体積スコア & $(0-25)$ & $2 \times \sqrt{\text { 体積 }(\mathrm{ml})-5}$ & $\mathrm{~g}$ \\
\hline 解剖スコア & $(0-25)$ & $\mathrm{g}$ & A \\
\hline 客観スコア & $(0-50)$ & $\mathrm{F}+\mathrm{A}$ & Obj \\
\hline 総合スコア & $(0-100)$ & $\mathrm{Sbj}+\mathrm{Obj}$ & $\mathrm{T}$ \\
\hline
\end{tabular}

*問診票は表 1 に従った。 
表 4 スコア値と実測値の対応

a . 尿流率スコア (15-最大尿流率)

\begin{tabular}{c||c||c|c|c|c|c||c}
\hline スコア & 0 & $\sim 3$ & $\sim 6$ & $\sim 9$ & $\sim 12$ & $\sim 15$ & 15 \\
\hline $\begin{array}{c}\text { 最大尿流率 } \\
(\mathrm{ml} / \text { 秒 })\end{array}$ & 15 以上 & $\sim 12$ & $\sim 9$ & $\sim 6$ & $\sim 3$ & $\sim 0$ & 0 \\
\hline
\end{tabular}

b. 残尿量スコア $(\sqrt{\text { 残尿量/4 }})$

\begin{tabular}{c||c||c|c|c|c|c||c}
\hline スコア & 0 & $\sim 2$ & $\sim 4$ & $\sim 6$ & $\sim 8$ & $\sim 10$ & 10 \\
\hline $\begin{array}{c}\text { 残 原 } \\
(\mathrm{ml})\end{array}$ & 0 & $\sim 16$ & $\sim 64$ & $\sim 144$ & $\sim 256$ & $\sim 400$ & 400 以上 \\
\hline
\end{tabular}

c. 前立腺体積スコア $(2 \times \sqrt{\text { 体積 }-5})$

\begin{tabular}{c||c||c|c|c|c|c||c}
\hline スコア & 0 & $\sim 5$ & $\sim 10$ & $\sim 15$ & $\sim 20$ & $\sim 25$ & 25 \\
\hline $\begin{array}{c}\text { 前立腺体積 } \\
(\mathrm{ml})\end{array}$ & 5 以下 & $\sim 11$ & $\sim 30$ & $\sim 61$ & $\sim 105$ & $\sim 161$ & 161 以上 \\
\hline
\end{tabular}

各スコア低值より 5 等分幅毎に, おおよそ, ほぼ正常, やや異常, 異常, かなり異常, 大変異常となる

ようにスコア化した。

客観的指標は，機能的指標と解剖学的指標とに分け て考えた。前者は尿流測定と残尿測定，後者は前立腺 超音波断層法の結果を用いた。尿流率は排尿量が 150 $\mathrm{ml}$ 以上もしくは最大尿意時の排尿について最大尿流 率を採用した。なお計測を複数回行った場合は，問診 票調査と大きな時間的ずれがない限り患者がより自然 の排尿に近いとした方を選択した。残尿はカテーテル 挿入による導尿量を測定した。超音波検査は経直腸的 断層法による前立腺体積を指標として採用した。超音 波所見上，仮想円面積比帛を有用な指標とする報告も あるが，測定の簡便性から体積だけとした。

他覚所見は既に数值化されており，再現性はほぼ良 好と考兄られるが，検査によって数值の持つ意味が異 なる，従って異なる検査間では，検査値自体はもちろ ん検査値の変動の割合を単純に比較することは無意味 である、そこで検査の枠をこえて対等に扱えるよう， 他覚所見もスコア化することを試みた。

まず機能的指標と解剖的指標のスコアを各々機能ス コアと解剖スコアとした。機能スコア（0〜25点）は, 最大尿流率と残尿量を表 3 に示した変換式でスコア化 し，それを加算した。解剖スコア（0〜25点）は前立 腺体積を表 3 に示した計算式によりスコア化した。こ れらの方法から得られた機能スコアと解剖スコアを加 え, 客観スコア（ 0 〜 50点）とした.

なお表 4 に示す通り，スコアへの変換はスコア低値 より 5 等分幅毎に，おおよそ，ほぼ正常，やや異常， 異常, かなり異常, 大変異常, に相当するように考慮 した.

3）綜合評価
主観的指標と客観的指標の綜合評価は, 主観スコア と客観スコアを単純に加算し, 総合スコア $(0 \sim 100$ 点 $)$ とした。

表 5 スコア值の分布

\begin{tabular}{c|c}
\hline スコア & mean $\pm \mathrm{SD}$ \\
\hline 主観的スコア & $17.1 \pm 9.7$ \\
症状スコア & $9.5 \pm 5.2$ \\
刺激症状 & $9.8 \pm 5.6$ \\
閉塞症状 & $9.1 \pm 6.3$ \\
QOL スコア & $7.6 \pm 5.3$ \\
客観的スコア & $18.1 \pm 5.8$ \\
機能スコア & $8.5 \pm 4.3$ \\
解剖スコア & $9.7 \pm 3.0$ \\
\hline 総合スコア & $35.4 \pm 12.3$ \\
\hline
\end{tabular}

図 1 総合スコア分布.

総合スコアの分布を10点刻みに示した。

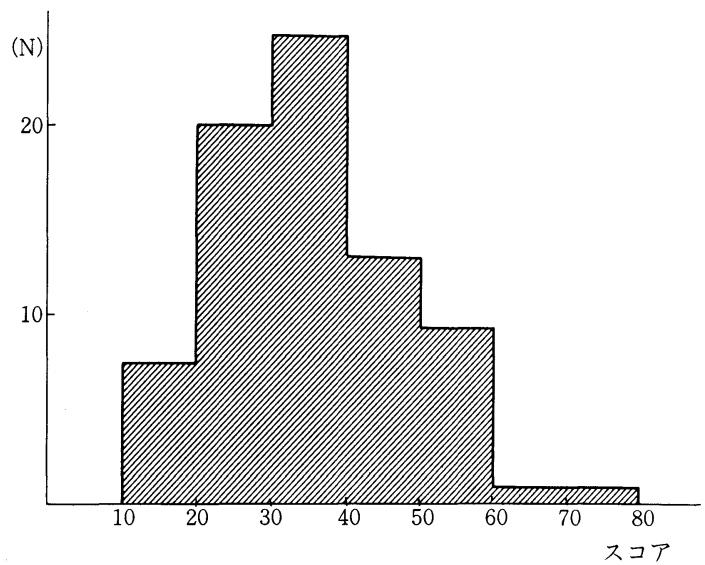


結果

適切な対象例でかつ全データのそろった77例（平均 $70.4 \pm 6.7$ 歳，55～84歳)について解析した。 まず全症 例のスコアの平均値の分布を表 5 と図 1 に示した。総 合スコアの分布の状態から，表 6 のように Grade 0は 10点未満, Grade 1は 10 点以上 20 点未満, Grade 2 は 20 点以上 30 点未満, Grade 3は 30 点以上 40 点未満, Grade 4 は 40 点以上 50 点未満, Grade 5 は 50 点以上と Grade 分 類した。

また症状スコア, QOL スコア, 機能スコア, 解剖ス コアの 25 点満点の 4 種のスコアの平均はいずれも 9 点 前後であった。従って個々の症例においては各スコア の絶対値を比較することでぞの指標が重症かを大体判 断できる，それを図示して理解しやすくするために， 一例として図 2 のような表示方法を示した。

表 6 Grade とスコア值

\begin{tabular}{c|c|c}
\hline Grade & スコア値 & 症 例 数 \\
\hline 0 & $<10$ & 0 \\
1 & $\geqq 10$ & 7 \\
2 & $\geqq 20$ & 20 \\
3 & $\geqq 30$ & 25 \\
4 & $\geqq 40$ & 13 \\
5 & $\geqq 50$ & 12 \\
\hline
\end{tabular}

図 2 排尿障害重症度の表示例。 各軸の原点からの距離が各スコアを示し, 縦軸全体が 主観スコア, 横軸全体が客観スコアを示す（この例で は症状が強くQOLの障害も強いが，機能的には中程 度の障害で解剖的には軽いことを示す.)

症状

スコア

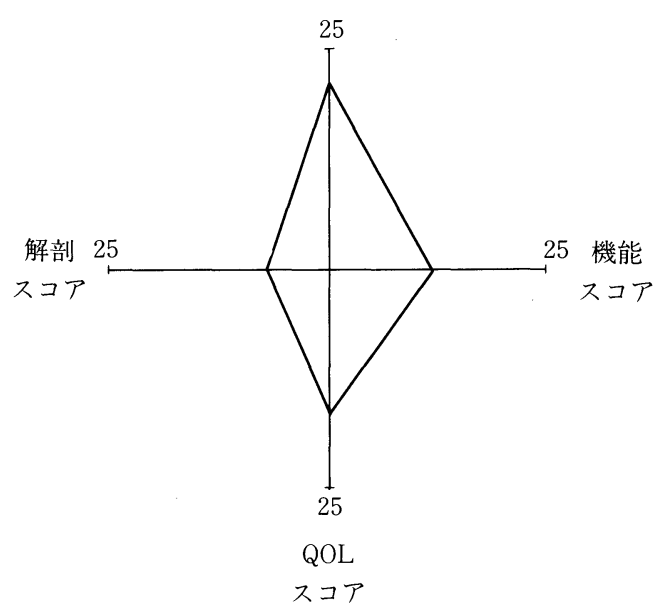

表 7 は各スコア值の相関を示した. 主観スコア内及 び客観スコア内では総体的に高い相関があったが，主 観スコアと客観スコアの間では相関はないことが示さ

表 7 前立腺肥大症のスコア値の相関性

\begin{tabular}{|c|c|c|c|c|c|c|c|c|c|c|c|c|c|}
\hline & 急 & $\begin{array}{l}\text { 症 } \\
\text { 状 }\end{array}$ & 刺 & $\begin{array}{l}\text { 閴 } \\
\text { 骞 }\end{array}$ & $\begin{array}{l}\mathrm{Q} \\
\mathrm{O} \\
\mathrm{L}\end{array}$ & $\begin{array}{l}\text { 不 } \\
\text { 快 }\end{array}$ & $\begin{array}{l}\text { 不 } \\
\text { 満 } \\
\end{array}$ & 客 & $\begin{array}{l}\text { 機 } \\
\text { 能 }\end{array}$ & $\begin{array}{l}\text { 尿 } \\
\text { 流 }\end{array}$ & 残 & $\begin{array}{l}\text { 解 } \\
\text { 剖 }\end{array}$ & $\begin{array}{l}\text { 総 } \\
\text { 合 }\end{array}$ \\
\hline 主観 & & (0) & 0 & 0 & (1) & & & & & & & & () \\
\hline $\begin{array}{l}\text { 症状 } \\
\text { 刺激 } \\
\text { 閉塞 }\end{array}$ & $\begin{array}{l}0 \\
0 \\
0\end{array}$ & $\begin{array}{l}\text { ()) } \\
\text { (9) }\end{array}$ & $\begin{array}{l}\odot \\
\triangle\end{array}$ & $\begin{array}{l}0 \\
\triangle\end{array}$ & $\begin{array}{l}0 \\
0 \\
\Delta\end{array}$ & & & & & & & & $\begin{array}{l}0 \\
0 \\
0\end{array}$ \\
\hline $\begin{array}{l}\text { QOL } \\
\text { 不快 } \\
\text { 不満 }\end{array}$ & $\begin{array}{l}(0) \\
0 \\
0\end{array}$ & $\begin{array}{l}0 \\
0 \\
0\end{array}$ & 0 & $\Delta$ & $\begin{array}{l}0 \\
0\end{array}$ & 0 & 0 & & & & & & $\begin{array}{l}0 \\
0 \\
\triangle\end{array}$ \\
\hline 客観 & & & & & & & & & () & 0 & $\triangle$ & 0 & 0 \\
\hline $\begin{array}{l}\text { 機能 } \\
\text { 尿流 } \\
\text { 残尿 }\end{array}$ & & & & & & & & $\begin{array}{l}0 \\
0 \\
\triangle\end{array}$ & $\begin{array}{l}(0) \\
0\end{array}$ & (O) & 0 & & $\begin{array}{l}\bigcirc \\
\triangle\end{array}$ \\
\hline 解剖 & & & & & & & & 0 & & & & & \\
\hline 総合 & () & 0 & 0 & 0 & 0 & 0 & $\Delta$ & 0 & 0 & $\triangle$ & & & \\
\hline
\end{tabular}

表示；相関係数は以下の通りである。

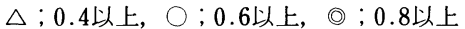


表 8 前立腺肥大症重症度判定用紙

\begin{tabular}{|c|c|c|c|}
\hline 刺激症状 & \multirow{5}{*}{$(a+b / 2)$} & $\underline{a}$ & 点 \\
\hline 閉塞症状 & & $\mathrm{b}$ & 点 \\
\hline 症状スコア & & $\mathrm{S}$ & 点 \\
\hline 不快・支障 & & $\mathrm{c}$ & 点 \\
\hline 不満 & & $\mathrm{d}$ & 点 \\
\hline QOL スコア & \multirow{2}{*}{$\begin{array}{l}(\mathrm{c}+\mathrm{d}) \\
(\mathrm{S}+\mathrm{L})\end{array}$} & $\mathrm{L}$ & 点 \\
\hline 主観スコア & & $\mathrm{Sbj}$ & 点 \\
\hline 最大尿流率 & \multirow{2}{*}{$\left.\begin{array}{ll}(\quad \mathrm{ml} / \mathrm{sec}) \\
\mathrm{ml}\end{array}\right)$} & $\mathrm{e}$ & 点 \\
\hline 残尿量 & & $\mathrm{f}$ & 点 \\
\hline 機能スコフ & $(e+f)$ & $\mathrm{F}$ & 点 \\
\hline 前立腺体積 & ( $\mathrm{ml}$ ) & $\mathrm{g}$ & 点 \\
\hline 解剖スコア & $(\mathrm{g})$ & $\mathrm{A}$ & 点 \\
\hline 客観スコア & $(\mathrm{F}+\mathrm{A})$ & $\mathrm{Obj}$ & 点 \\
\hline \multirow[t]{2}{*}{ 総合スコア } & \multirow[t]{2}{*}{$(\mathrm{Sbj}+\mathrm{Obj})$} & & 点 \\
\hline & & & 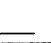 \\
\hline
\end{tabular}

e : 15 -最大尿流率 (最大 15 ), f : $\sqrt{\text { 残尿量 } / 4}$ (最大 10 )

$\mathrm{g}: 2 \sqrt{\text { 体積 }-5}$ (最大 25 )

れた。 また個々の症例で便利なように表 8 の重症度判 定用紙を作成した。

\section{考察}

前立腺肥大症の臨床病期分類としては従来第 1 期は 刺激症状，第 2 期は閉塞症状，第 3 期は膀胱の非代償 期などとされてきた。その後超音波断層法，尿流率測 定などの診断法の発達によって，より総合的な前立腺 肥大症の評価が可能となった。しかし種々の検査法の 発達があっても，個々の症例の重症度の把握の方法が 一定していないため, 症例間の重症度の比較, ある症 例での治療による重症度の変化，ある治療法の有効性 及び治療法間の有効性の比較などが困難となってい る、今回の研究では，こうした不都合を解決するため に，前立腺肥大症による症状や所見を総合した重症度 分類を試みた。なお，尿閉やそれに起因する水腎症な ぞを有する症例は別途に扱うべきでこの分類では考慮 しなかった。

前立腺肥大症の病状を把握する上での基本的立脚点 として以下の 3 点を打いた。即ち

(1) 評価する指標を狭く限定しない。

(2) 各指標は対等に扱 5 .

(3) 取扱いの便宜上各指標の評価は数量化する.

の 3 点である。まず指標の採択にあたっては，大きく 主観的指標と客観的指標の 2 つを設定した。更に前者 は排尿症状と QOL 障害に, 後者は機能的障害と解剖 学的異常とに細分割し, 計 4 指標とした。これにより, 前立腺肥大症に起因する病態をほぼ包括できると考古
た ${ }^{8) 10) \sim 12)}$. つづいてこれら 4 つの指標を数量化しかつ 対等に扱うべく，各指標を 25 点満点でスコア化できる よう評価方法を考案した。

まず主観的指標については，国際前立腺症状スコ $ア^{8)}$ に準拠し，既に報告された方法(6)7 も参考とした。排 尿症状ではいわゆる閉塞症状と刺激症状が存在するの で，これを対等のスコア值となるようにした。 QOLに ついては同程度の症状を有していてもその QOL の障 害は必ずしも同一ではないこと年，また前立腺肥大症 は良性疾患であり, 評価上 QOL は重要な要素である ことを考完, QOL と症状をスコア上対等に扱らように した。この方針に従って国際前立腺症状スコアを一部 修正した。第一の修正は, 本研究では刺激症状と閉塞 症状の問診項目数を同一とするため, 刺激症状を 1 項 目（表 1 [1] -1）と閉塞症状を 2 項目（表 1 [1］-3, 4）追加した。第二は QOL については更に細分して問 診すべく 4 項目を追加した（表 1 [2] - - 1，2，3，4）. 第三は国際前立腺症状スコアでは不満足度は 6 点満点 であったが, QOL スコアを 25 点満点とするために 5 点 満点に改めた。このため問診項目は合計15項目となり 煩雑な印象を与兄るが，実際の記入は10分以内で終了 し実用性に問題はなかった。しかし自覚症状は消長が 激しく10) 14), placebo 効果もかなり認められることが 知られており ${ }^{12) 13)}$, 主観的指標だけで前立腺肥大症の 全貌を把握することは困難と考えられる。

客観的指標については，スコアを機能スコアと解剖 スコアとに分類した。これにより今後より良い検査が 一般化した場合を想定しても，その検査結果が機能的 指標か解剖的指標かによって分類すれば分類項目自体 を変更せずに扱らことができると考えた。そのような 新しい機能的検查としては Pressure-flow study, 解剖 的検査として腺腫部分のみの重量測定や膀胱頸部の形 態などがあろう。

つづいて客観的指標に用いた検查の妥当性を検討す る。すず尿流率については, 加齢とともに尿流率は低 下寸る ${ }^{1115)}$ ，尿道閉塞と膀胱利尿筋低活動は尿流率の

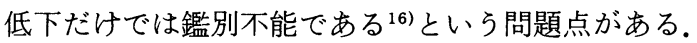
しかし閉塞の進行に伴い尿流率が低下することも明ら かで17)，検査の低侵襲性からも採用すべき検査と考兄 られる(6)8)10) 12). 残尿については, 同一症例内での変動 が激しく ${ }^{12)}$, 尿道閉塞との相関に関しても見解は一定 しないが11118)，排尿障害の指標としては無視できな (668)101 12) と思われる。なお今回は残尿をカテーテル 挿入で測定したが，経腹的超音波測定で十分代用でき 
るので19)，今後は侵襲の少ない超音波検査を用いるべ きであろう。

前立腺体積も症状や尿流率などと相関しないとされ るが20), 疾患の本体でもある前立腺の腫大を評価項目 としないのは無理があろ ${ }^{6(8) 101012)}$. 以上, 多数ではあ るがこれらの検査を採択する妥当性はあるものと考兄 られよう。

スコア評価においては，各スコアはほぼ等しい平均 值をとり, 症例間の重症度のみならず特定の症例の指 標間の重症度の比較もスコア值だけでおおよそ可能で あると思われた。また，各スコア間の相関性は必ずし も高いものではなかった。特に主観スコアと客観スコ アの間の相関性は低かった。これは主観的症状と客観 的検査全般の間14)21), 症状と尿流率1116) 18)21222), 症状 之尿道抵抗 ${ }^{16)}$, 症状之前立腺体積との間の相関は低 (20)とする報告に一致するものである。このように指 標間の独立性が高いと考えられるので，やや煩雑では あるが多数のパラメーターによる評価911112) 方法は止 むを得ないことと思われる。

今後の課題としては，このスコア化の妥当性を更に 検討すること, 及びこの重症度にもとづいて治療効果 を判定することがある。

まず妥当性については，採用している指標の種類と スコア化拉よび統合化の 3 点が問題である。まず指標 の種類とスコア化については, 特に問診項目や形式に 問題があろう。例えば刺激症状は頻度の多少で重症度 をつけやすいが, 閉塞症状はその程度または頻度と程 度の両者を尋ねる形式の方が望ましいかもしれない。 また QOL は各症状について不満度を評価して加算す るといら方法もあろう。しかし今回の研究では, 国際

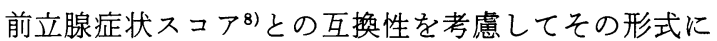
従った。また自覚症状は変動が激しくやや信頼性にも 欠けるので10) 13)，著しく不都合でない限り，問診票の 僅かの違いには大きな意味はないと考えられる。

指標のスコア化の方法については数学的な処理が必 要で, 特に客観的指標のスコア变換式はあくまでも暫 定的なものである。しかし変換の計算は実際にはそれ ほど面倒でもなく，各指標のスコア值を比較すること で指標間の重症度の比較も容易なことから，検査值そ のものを扱うょり有利と考兄られよう。

指標の統合化では，検查項目が多く一項目でも欠け ると総合スコアが出せないという批判もあろう。従っ て, 総合スコア以外に主観スコアまたは客観スコアの みによる主観, 客観別の重症度も考慮すべきであろう。
更に，主観・客観別の重症度を考慮することは，主観 スコアと客観スコアの間に相関性が低かったことか らったとえデータがすべて揃っていても必要であろう。 また，主観スコアと客観スコアの間に相関がなかった ことは，総合的判定を行う場合にはその一方のみでは 不十分であるという主張8)11221を改めて裏付けるもの である。

最後に治療効果の判定については，スコア值の変化 率または Grade の移行をもって効果の指標とすべき と考学られる。その変化率または移行と効果判定の設 定は今後の検討を要する，例郎ばスコア值 $50 \%$ 以上の 減少または Gradeの 3 段階以上の改善を著効, スコア 值の $25 \%$ 以上の減少または Gradeの 2 段階以上の改 善とGrade 0への移行を有効とするなどを試案として 考えている.

\section{結語}

排尿症状と QOL の調査, 尿流測定, 残尿測定, 経直 腸的超音波断層法の結果を用いて，前立腺肥大症の重 症度をスコア化し，Grade 分類を提案した，その妥当 性, 実用性, 効果判定の有用性については今後更に検 討を要する。

\section{文献}

1) Lepor, H.: Nonoperative mana'gement of benign prostatic hyperplasia. J. Urol., 141, 1283-1289, 1989.

2) Chapple, C.R., Milroy, E.J.G. and Rickards, D. : Permanently implanted urethral stent for prostatic obstruction in the unfit patient. Preliminary Report. Br. J. Urol., 66, 58-65, 1990.

3) Dowd, J.B. and Smith, J.J. III : Balloon dilatation of the prostate. Urol. Clin. North Am., 17, 671-677, 1990.

4）本間之夫, 小澤輝晃, 東原英二, 阿曾佳郎：前立腺 肥大症に対するプロスタサマーによる温熱療法の 治療成績。日泌尿会誌，82，792-798，1991.

5) Devonec, M., Berger, N. and Perrin, P.: Transurethral microwave heating of the prostate -or from hyperthermia to thermotherapy. J. Endourol., 5, 129-135, 1991.

6) Boyarsky, S., Jones, G., Paulson, D.F. and Prout, G.R. Jr.: A new look at bladder neck obstruction by the food drug administration regulators: Guide lines for investigation of benign prostatic hypertrophy. J. Urol., 68, 29-31, 1977.

7) Madsen, P.O. and Iversen, P.: A point system for selecting operative candidates. in Hinman, F., Boyarsky, S (eds.) : Benign prostatic hyper- 
trophy. p. 763-765, Springer-Verlag, New York, 1983.

8) Cockett, A.T., Aso, Y., Denis, L. and Khoury, S. : 世界保健機構前立腺肥大症取扱、委員会規 約答申. in Proceedings of the international consultation on benign prostatic hyperplasia. $\mathrm{p}$. $311-319,1991$.

9）大江 宏, 斉藤雅人, 田中重喜, 板倉康啓, 渡辺 決：前立腺肥大症の超音波診断（第 2 報）一前立腺 肥大症の成り立ちと仮想円面積比一. 日超医論文 集, 32, 121-122, 1977.

10) Fowler, F.J. : Patient reports of symptoms and quality of life following prostate surgery. Eur. Urol., 20, 44-49, 1991.

11) Christensen, M.M. and Bruskewitz, R.C. : Clinical manifestations of benign prostatic hyperplasia and indications for therapeutic intervention. Urol. Clin. North Am., 17, 509-516, 1990.

12) Wein, A.J.: Evaluation of treatment response to drugs in benign prostatic hyperplasia. Urol. Clin. North Am., 17, 631-640, 1990.

13) Barry, M.J.: Epidemiology and natural history of benign prostatic hyperplasia. Urol. Clin. North Am., 17, 495-507, 1990.

14) Frimodt-M $\phi$ ller, P.C., Jensen, K.M.E., Iversen, P., Madsen, P.O. and Bruskewitz, R.C.: Analysis of presenting symptoms in prostatism. J. Urol., 132; 272-276, 1984.

15) J $\phi$ rgensen, J.B., Jensen, K.M.E. and Mogensen, P. : Age-related variation in urinary flow variables and flow curve patterns in elderly males.
Br. J. Urol., 69, 265-271, 1991.

16) Schäfer, W.: Principles and clinical application of advenced urodynamic analysis of voiding function. Urol. Clin. North Am., 17, 553-566, 1990.

17) Jensen, K.M.E., J $\phi$ rgensen, J.B. and Mogensen, P.: Urodynamics in prostatism. I. Prognostic value of uroflowmetry. Scand. J. Urol. Nephrol., 22, 109-117, 1988.

18) Andersen, J.T., Nordling, J. and Walter, S. : Prostatism. I. The correlation between symptoms, cystometric and urodynamic findings. Scand. J. Urol. Nephrol., 13, 229-236, 1979.

19) Orgaz, R.E., Gomez, A.Z., Ramirez, C.T. and Torres, J.L.M.: Application of bladder ultrasonography. I. Bladder content and residue. J. Urol., 125, 174-176, 1981.

20) Jensen, K.M.E., Bruskewitz, R.C., Iversen, P., Madsen, P.O.: Significance of prostatic weight in prostatism. Urol. Int., 38, 173-178, 1983.

21) Herbison, A.E., Fraundorfer, M.R. and Walton, J.K.: Association between symptomatology and uroflowmetry in benign prostatic hypertrophy. Br. J. Urol., 62, 427-430, 1988.

22) Cucchi, A.: Urinary flow rate in benign prostatic hypertrophy in relation to the degree of obstruction of the vesical outlet. Br. J. Urol., 69, 272-276, 1992.

(1992年 9 月 8 日受理, 特別掲載) 